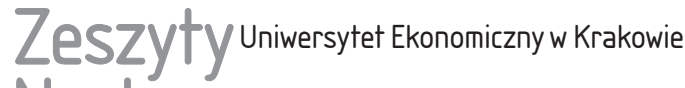 Naukowe
}

$10(946)$

ISSN 1898-6447

Zesz. Nauk. UEK, 2015; 10 (946): 53-74 DOI: 10.15678/ZNUEK.2015.0946.1004

Wojciech Zysk

Katedra Handlu Zagranicznego

Uniwersytet Ekonomiczny w Krakowie

\section{Wpływ procesów integracyjnych na handel międzynarodowy - przypadek krajów rozwijających się}

\section{Streszczenie}

W opracowaniu podjęto próbę weryfikacji tezy, że pozytywne efekty procesów międzynarodowej regionalnej integracji gospodarczej krajów rozwijających się prowadzą do wzrostu wartości wymiany handlowej zarówno w zakresie stopy wzrostu eksportu i importu, jak i wzrostu udziału eksportu i importu w całości wymiany handlowej wewnątrz tworzonych ugrupowań. Międzynarodowa integracja państw rozwijających się przynosi tym krajom korzyści w ramach tworzonych ugrupowań na skutek zniesienia ceł i redukcji barier we wzajemnych obrotach. Stopa wzrostu eksportu i importu wewnątrz danego ugrupowania jest na ogół wyższa niż stopa wzrostu handlu w ramach reszty regionu i reszty świata, a udział eksportu i importu wewnętrznego w całkowitym eksporcie i imporcie jest na ogół wyższy niż udział eksportu i importu z resztą świata w całkowitym eksporcie i imporcie.

Słowa kluczowe: kraje rozwijające się, efekty integracji regionalnej, handel międzynarodowy, ugrupowania regionalne.

\section{Wprowadzenie}

Liberalizacja wymiany handlowej postępuje w efekcie zawierania międzynarodowych umów handlowych zarówno na szczeblu WTO (choćby Pakiet z Bali 
w ramach Rundy Doha), jak i w instytucjonalnych ramach regionalnych umów o preferencjach handlowych.

Celem niniejszego opracowania jest próba empirycznej weryfikacji następujących tez badawczych:

1) międzynarodowa integracja państw rozwijających się przynosi tym krajom korzyści w postaci wzrostu wartości wymiany handlowej w ramach tworzonych ugrupowań (w dwóch kierunkach: eksport, import; licząc od daty utworzenia danego ugrupowania) na skutek zniesienia ceł i redukcji barier we wzajemnych obrotach, co więcej, stopa wzrostu eksportu i importu wewnątrz danego ugrupowania jest wyższa niż stopa wzrostu handlu w ramach reszty regionu i reszty świata;

2) udział eksportu i importu wewnętrznego (w ramach utworzonych ugrupowań regionalnych, licząc od daty utworzenia danego ugrupowania) w całkowitym eksporcie i imporcie jest wyższy niż udział eksportu i importu z resztą świata w całkowitym eksporcie i imporcie.

Ważne jest zaznaczenie w tym miejscu, że członkami niektórych badanych organizacji oprócz krajów rozwijających się są kraje rozwinięte (np. w APEC). Dla pełnego obrazu przeprowadzonych badań nie wykluczono tych ugrupowań, zwłaszcza że UNCTAD w swych statystykach umieszcza takie podmioty wśród analiz ugrupowań regionalnych (por. http://stats.unctad.org/Handbook, dostęp: 5.08.2014). Zdaniem autora pominięcie wspomnianych organizacji w niniejszym opracowaniu wpłynęłoby negatywnie na wyniki przeprowadzonych badań.

Problematyką skutków międzynarodowej integracji gospodarczej (na różnych jej etapach) dla handlu międzynarodowego zajmowało się wielu badaczy. Analiza przedmiotowych zagadnień prowadzona była w odniesieniu do krajów Unii Europejskiej (m.in. [Nowak-Lehmann i in. 2007, s. 719; Chen i Novy 2011, s. 20; Czarny i in. 2013, s. 55]), zawieranych przez nią umów bilateralnych z innymi krajami [Soete i Hove 2013, s. 1], krajów rozwijających się [Hoekman, Ng i Olarreaga 2002, s. 12; Lee i Kim 2012, s. 67; Rynarzewski 2013, s. 70; Piekutowska 2014, s. 88; Melo i Tsikata 2014, s. 3] czy grup państw, które podpisały umowy o wolnym handlu [Venables 2003, s. 747; Ghosh i Yamarik 2004, s. 213; Baier i Bergstrand 2007, s. 72; Helpman, Melitz i Rubinstein 2008, s. 441; Magee 2008, s. 340; Czarny, Menkes i Śledziewska 2009, s. 125; Freund i Ornelas 2010, s. 139; Chen i Mattoo 2011, s. 838; Anderson i Yotov 2011, s. 18; Portugal-Perez i Wilson 2012, s. 1295; Eicher, Henn i Papageorgiou 2012, s. 296; Kovak 2013, s. 1960; Baier, Bergstrand i Feng 2014, s. 339]. Ze względu na ograniczoną objętość niniejszego opracowania nie sposób przedstawić wyników powyższych analiz, warto jednak zaznaczyć, że przeważają pozytywne efekty handlowe zawartych umów liberalizujących wymianę towarową. W zależności od poziomu i zakresu danej umowy liberalizującej handel między stronami porozumienie takie 
może przynieść efekty na wielu płaszczyznach życia gospodarczego. Umowy o szerokim zakresie i wysokim stopniu szczegółowości (UE, NAFTA) skutkują wieloma zobowiązaniami partnerów (również pozahandlowymi, dotyczącymi np. przestrzegania praw człowieka), natomiast mniej rozbudowane porozumienia - np. podpisywane przez kraje rozwijające się - dotyczą najczęściej tylko zobowiązań ułatwiających handel. To właśnie te ugrupowania regionalne są przedmiotem prezentowanych w pracy badań, zwłaszcza że badania obejmują okres od daty utworzenia danego ugrupowania do 2012 r. i dwa kierunki wymiany, czyli eksport i import.

\section{Teoretyczne aspekty międzynarodowej integracji gospodarczej}

W literaturze przedmiotu wymienia się wiele korzyści i efektów, które mogą osiągnąć państwa angażujące się w poszczególne stadia czy procesy międzynarodowej integracji gospodarczej [Balassa 1962, s. 2; Kindleberger 1966, s. 71; Yannopoulos 1990, s. 247; Wybrane problemy... 1995, s. 7; Witkowska i Wysokińska... 1999, s. 122; Bożyk, Misala i Puławski 1999, s. 503; Hansen 2003, s. 11]. Do najważniejszych z nich można zaliczyć [Pozaeuropejskie ugrupowania... 2006, s. 19]:

1) efekty statyczne:

- efekt kreacji handlu (i wynikające z niego: rozszerzenie handlu, zewnętrzną kreację handlu, pełną kreację handlu, odchylenie handlu, efekt konsumpcyjny, efekt produkcyjny),

- efekt przesunięcia handlu (i wynikające z niego: destrukcję handlu i ograniczenie handlu),

2) efekty dynamiczne:

- korzyści skali, możliwe wskutek zwiększenia rozmiaru rynku,

- efektywną alokację zasobów,

- zwiększenie konkurencji, zmiany struktur rynkowych i strategii konkurencyjności przedsiębiorstw,

- stymulację inwestycji,

- rozwój handlu wewnątrzgałęziowego.

Efekt kreacji handlu (trade creation effect) oznacza wzrost wzajemnych obrotów handlowych w wyniku usunięcia ceł i innych barier oraz wprowadzenia wspólnej zewnętrznej taryfy celnej. Efekt ten jest uważany za pozytywny w przeciwieństwie do efektu przesunięcia handlu (trade diversion effect), który polega na zwiększeniu udziału krajów należących do unii celnej w handlu krajów członkowskich oraz zmniejszeniu udziału krajów trzecich w wyniku przesunięcia się źródeł zakupu towarów z krajów charakteryzujących się nawet niższymi kosztami 
produkcji, lecz pozostających na zewnątrz unii, do krajów wchodzących w jej skład. Suma tych 2 efektów decyduje o ekonomicznych skutkach powstania danego ugrupowania integracyjnego. Następstwem tych efektów może być ekspansja handlu (gdy wielkość handlu światowego rośnie wskutek wzrostu popytu, spadku cen i wystąpienia nowych możliwości wymiany w krajach partnerskich unii i poza nią) lub ograniczenie handlu (gdy organizacja głównie przesuwa handel, a nie kreuje go, następuje zmniejszenie wielkości handlu światowego) [Międzynarodowe stosunki gospodarcze... 2006, s. 297]. Efekty kreacji handlu oraz przesunięcia handlu występują zazwyczaj jednocześnie, ale różna jest ich siła. O tym, który z efektów przeważa, może decydować poziom ceł i innych barier handlowych w momencie integracji, poziom rozwoju gospodarczego krajów partnerskich oraz ich liczba i wielkość, struktura produkcji w integrujących się krajach czy bliskość geograficzna (koszty transportu) i kulturowa [Zielińska-Głębocka 1997, s. 218; Świerkocki 2004, s. 154].

\section{Metodologia badań}

Kraje rozwijające się to najbiedniejsze państwa na świecie wyróżniane na podstawie następujących kryteriów: ekonomicznego, demograficznego i społecznego. Najczęściej stosowanymi miarami służącymi do porównywania poziomu rozwoju gospodarczego krajów są PKB per capita oraz wskaźnik rozwoju społecznego HDI (human development index). Produkt krajowy brutto obliczany jest jako różnica między wartością dóbr materialnych i usług niematerialnych kraju a zużyciem pośrednim, czyli wartością kosztów materialnych i kosztów zakupu obcych usług niematerialnych. PKB obliczany jest $\mathrm{w}$ dolarach amerykańskich na jednego mieszkańca według parytetu siły nabywczej, czyli rzeczywistej wartości USD na rynkach wewnętrznych poszczególnych krajów. Wskaźnik rozwoju społecznego HDI to wskaźnik używany przez ONZ, określający 3 podstawowe zmienne: zdrowie i długość życia (mierzone oczekiwaną długością życia w dniu narodzin, mają na nią wpływ m.in. poziom wyżywienia, poziom higieny i usług medycznych), dostęp do wiedzy (mierzony wskaźnikiem skolaryzacji i alfabetyzacji) oraz standard życia (mierzony poziomem dochodu narodowego PKB na mieszkańca). Wskaźnik HDI przyjmuje wartości od 0 do 1 , przy czym 1 oznacza najwyższy poziom rozwoju społecznego (por. www.globaldevelopment.org.pl, dostęp: 5.08.2014). Kraje słabo rozwinięte to państwa, w których PKB nie przekracza 3000 USD na jednego mieszkańca, a wskaźnik HDI przyjmuje wartości poniżej 0,50. Jest to bardzo zróżnicowana grupa krajów, dlatego wyróżnia się w niej często grupę krajów najbiedniejszych, czyli takich, których PKB nie przekracza 400 USD na osobę. Kraje słabo rozwinięte położone są przede wszystkim w Afryce Środkowej, Azji Południowo- 
-Wschodniej oraz Ameryce Południowej i Środkowej. Kraje słabo rozwinięte cechują się m.in. eksplozją demograficzną, niedożywieniem i głodem, niskim standardem życia, wysoką umieralnością niemowląt, analfabetyzmem, zacofaniem technologicznym, surowcowym charakterem eksportu i rosnącym zadłużeniem zagranicznym [Bagiński, Czaplicka i Szczyciński 2009, s. 20; Kraje rozwijajace się... 2007, s. 175; The Least Developed Countries... 2012, s. 4].

$\mathrm{Na}$ podstawie danych liczbowych zamieszczonych na stronie internetowej UNCTAD (http://stats.unctad.org/Handbook, dostęp: 5.08.2014) obliczono dla 16 wybranych ugrupowań regionalnych (licząc od daty utworzenia danego ugrupowania do 2012 r. i uwzględniając wartości eksportu i importu w mln USD):

- dynamikę rozwoju (w \%) eksportu i importu wewnętrznego (w ramach danego ugrupowania),

- dynamikę rozwoju (w \%) eksportu i importu danego ugrupowania z resztą regionu,

- dynamikę rozwoju (w \%) eksportu i importu danego ugrupowania z resztą świata.

W dalszej części badań:

- obliczono zmianę udziału (w \%) eksportu i importu wewnętrznego w całkowitym eksporcie i imporcie,

- obliczono zmianę udziału (w \%) eksportu i importu zewnętrznego (reszta świata) w całkowitym eksporcie i imporcie,

- w celach porównawczych zamieszczono informację o zmianach udziału eksportu i importu zewnętrznego (reszta regionu) w całkowitym eksporcie i imporcie.

W ramach przeprowadzonych badań analizie poddano 16 ugrupowań i układów na świecie, które są na różnych etapach międzynarodowej integracji: od luźnego związku krajów (np. APEC), poprzez strefę wolnego handlu (np. COMESA czy LAIA), aż do unii celnych (CACM, GCC). Ważne jest jedno: w każdym badanym ugrupowaniu redukowano bariery celne i inne ograniczenia we wzajemnym handlu, liberalizowano zasady wzajemnego handlu, dążono do koordynacji współpracy oraz pogłębiano integrację regionalną w celu uzyskania wzrostu gospodarczego, podnoszenia standardów i jakości życia, eliminacji biedy, a także promocji i obrony pokoju i bezpieczeństwa.

\section{Wyniki badań}

W tabelach 1-32 przedstawiono wyniki badań - obliczenia zgodne z przyjętą metodologią dla analizowanych ugrupowań - a poniżej opatrzono je krótkimi komentarzami. 
Wspólnota Ekonomiczna Krajów Wielkich Jezior (CEPGL) powstała w 1976 r. i zrzesza Burundi, Rwandę i Zair.

Jak można zauważyć w tabelach 1 i 2 , dynamika rozwoju eksportu i dynamika rozwoju importu były najwyższe wewnątrz ugrupowania (odpowiednio 9353\% i $6738 \%$ ), podobnie jak zmiany eksportu i importu w całkowitym eksporcie i imporcie (odpowiednio 1100\% i 667\%).

Tabela 1. Dynamika rozwoju eksportu i importu CEPGL

\begin{tabular}{|l|c|c|c|c|}
\hline \multicolumn{1}{|c|}{ Kierunek handlu } & Lata & $\begin{array}{c}\text { Wewnątrz } \\
\text { ugrupowania }\end{array}$ & Reszta regionu & Reszta świata \\
\hline Eksport (mln USD) & 1976 & 1,6 & 10,8 & 951,7 \\
\hline Eksport (mln USD) & 2012 & 151,7 & 338,7 & 1821,1 \\
\hline Dynamika (\%) & - & 9353 & 3135 & 191 \\
\hline Import (mln USD) & 1976 & 2,8 & 160,5 & 1000,8 \\
\hline Import (mln USD) & 2012 & 185,9 & 3343,3 & 9072,8 \\
\hline Dynamika (\%) & - & 6738 & 2083 & 907 \\
\hline
\end{tabular}

Źródło: opracowanie własne na podstawie http://stats.unctad.org/Handbook (dostęp: 5.08.2014).

Tabela 2. Zmiany udziału eksportu i importu CEPGL w całkowitym eksporcie i imporcie (w \%)

\begin{tabular}{|l|c|c|c|c|}
\hline \multicolumn{1}{|c|}{ Kierunek handlu } & Lata & $\begin{array}{c}\text { Wewnątrz } \\
\text { ugrupowania }\end{array}$ & Reszta regionu & Reszta świata \\
\hline Udział eksportu & 1976 & 0,2 & 86,9 & 99,8 \\
\hline Udział eksportu & 2012 & 2,2 & 69,1 & 97,8 \\
\hline Dynamika & - & 1100 & 80 & 98 \\
\hline Udział importu & 1976 & 0,3 & 98,3 & 99,7 \\
\hline Udział importu & 2012 & 2,0 & 94,7 & 98,0 \\
\hline Dynamika & - & 667 & 96 & 98 \\
\hline
\end{tabular}

Źródło: jak w tabeli 1.

Środkowoafrykańska Wspólnota Gospodarcza i Walutowa (CEMAC) powstała w 1994 r. Należą do niej Kamerun, Republika Centralnej Afryki, Czad, Kongo, Gwinea Równikowa i Gabon.

W przypadku CEMAC (tabele 3 i 4) dynamika rozwoju eksportu była najwyższa wewnątrz ugrupowania (1276\%), dynamika rozwoju importu była wyższa w handlu z resztą regionu (1826\%), a zmiany udziału eksportu i importu w całkowitym eksporcie i imporcie były największe wewnątrz ugrupowania (odpowiednio 145\% i 141\%). 
Wpływ procesów integracyjnych na handel międzynarodowy...

Tabela 3. Dynamika rozwoju eksportu i importu CEMAC

\begin{tabular}{|l|c|c|c|c|}
\hline \multicolumn{1}{|c|}{ Kierunek handlu } & Lata & $\begin{array}{c}\text { Wewnątrz } \\
\text { ugrupowania }\end{array}$ & Reszta regionu & Reszta świata \\
\hline Eksport (mln USD) & 1994 & 55,6 & 198,6 & 4902,3 \\
\hline Eksport (mln USD) & 2012 & 709,3 & 832,5 & 44264,7 \\
\hline Dynamika (\%) & - & 1276 & 419 & 903 \\
\hline Import (mln USD) & 1994 & 46,7 & 151,6 & 2083,4 \\
\hline Import (mln USD) & 2012 & 838,7 & 2768,5 & 26392,4 \\
\hline Dynamika (\%) & - & 1796 & 1826 & 1267 \\
\hline
\end{tabular}

Źródło: jak w tabeli 1.

Tabela 4. Zmiany udziału eksportu i importu CEMAC w całkowitym eksporcie i imporcie (w \%)

\begin{tabular}{|l|c|c|c|c|}
\hline Kierunek handlu & Lata & $\begin{array}{c}\text { Wewnątrz } \\
\text { ugrupowania }\end{array}$ & Reszta regionu & Reszta świata \\
\hline Udział eksportu & 1994 & 1,1 & 78,1 & 98,9 \\
\hline Udział eksportu & 2012 & 1,6 & 54,0 & 98,4 \\
\hline Dynamika & - & 145 & 69 & 99 \\
\hline Udział importu & 1994 & 2,2 & 76,5 & 97,8 \\
\hline Udział importu & 2012 & 3,1 & 76,7 & 96,9 \\
\hline Dynamika & - & 141 & 100 & 99 \\
\hline
\end{tabular}

Źródło: jak w tabeli 1.

Wspólny Rynek Afryki Wschodniej i Południowej (COMESA) skupia Burundi, Demokratyczną Republikę Kongo, Dżibuti, Egipt, Erytreę, Etiopię, Kenię, Komory, Libię, Madagaskar, Malawi, Mauritius, Rwandę, Seszele, Suazi, Sudan, Ugandę, Zambię oraz Zimbabwe. Organizacja ta powstała w 1994 r.

Na podstawie zaprezentowanych danych (tabele 5 i 6) można zauważyć, że dynamika rozwoju eksportu i dynamika rozwoju importu były najwyższe wewnątrz ugrupowania (odpowiednio 794\% i 823\%), podobnie jak zmiany udziału eksportu i importu w całkowitym eksporcie i imporcie (odpowiednio 121\% i 123\%).

Wspólnota Gospodarcza Państw Afryki Srodkowej (ECCAS) powstała w 1983 r. Należą do niej Angola, Burundi, Czad, Demokratyczna Republika Konga, Gabon, Gwinea Równikowa, Kamerun, Kongo, Republika Środkowoafrykańska, Wyspa Świętego Tomasza i Wyspa Książęca.

W przypadku tego ugrupowania (tabele 7 i 8) dynamika rozwoju eksportu, importu oraz zmiany udziału eksportu w całkowitym eksporcie były najwyższe w handlu z resztą regionu (odpowiednio 3977\%, 3316\% i 163\%). Tylko zmiany 
udziału importu w całkowitym imporcie były największe w wymianie wewnątrz ECCAS (118\%).

Tabela 5. Dynamika rozwoju eksportu i importu COMESA

\begin{tabular}{|l|c|c|c|c|}
\hline \multicolumn{1}{|c|}{ Kierunek handlu } & Lata & $\begin{array}{c}\text { Wewnątrz } \\
\text { ugrupowania }\end{array}$ & Reszta regionu & Reszta świata \\
\hline Eksport (mln USD) & 1994 & 1171,0 & 1225,8 & 19478,9 \\
\hline Eksport (mln USD) & 2012 & 9296,7 & 6852,9 & 124766,3 \\
\hline Dynamika (\%) & - & 794 & 559 & 641 \\
\hline Import (mln USD) & 1994 & 1243,4 & 2326,6 & 25279,9 \\
\hline Import (mln USD) & 2012 & 10230,9 & 14929,6 & 164918,7 \\
\hline Dynamika (\%) & - & 823 & 642 & 652 \\
\hline
\end{tabular}

Źródło: jak w tabeli 1.

Tabela 6. Zmiany udziału eksportu i importu COMESA w całkowitym eksporcie i imporcie (w \%)

\begin{tabular}{|l|c|c|c|c|}
\hline \multicolumn{1}{|c|}{ Kierunek handlu } & Lata & $\begin{array}{c}\text { Wewnątrz } \\
\text { ugrupowania }\end{array}$ & Reszta regionu & Reszta świata \\
\hline Udział eksportu & 1994 & 5,7 & 51,1 & 94,3 \\
\hline Udział eksportu & 2012 & 6,9 & 42,4 & 98,4 \\
\hline Dynamika & - & 121 & 83 & 104 \\
\hline Udział importu & 1994 & 4,7 & 65,2 & 95,3 \\
\hline Udział importu & 2012 & 5,8 & 59,3 & 96,9 \\
\hline Dynamika & - & 123 & 91 & 102 \\
\hline
\end{tabular}

Źródło: jak w tabeli 1.

Tabela 7. Dynamika rozwoju eksportu i importu ECCAS

\begin{tabular}{|l|c|c|c|c|}
\hline \multicolumn{1}{|c|}{ Kierunek handlu } & Lata & $\begin{array}{c}\text { Wewnątrz } \\
\text { ugrupowania }\end{array}$ & Reszta regionu & Reszta świata \\
\hline Eksport (mln USD) & 1883 & 103,7 & 100,0 & 6417,8 \\
\hline Eksport (mln USD) & 2012 & 990,0 & 3976,8 & 125019,3 \\
\hline Dynamika (\%) & - & 955 & 3977 & 1948 \\
\hline Import (mln USD) & 1883 & 77,1 & 241,6 & 4413,6 \\
\hline Import (mln USD) & 2012 & 1207,3 & 8010,5 & 59429,9 \\
\hline Dynamika (\%) & - & 1566 & 3316 & 1347 \\
\hline
\end{tabular}

Źródło: jak w tabeli 1. 
Tabela 8. Zmiany udziału eksportu i importu ECCAS w całkowitym eksporcie i imporcie (w \%)

\begin{tabular}{|l|c|c|c|c|}
\hline \multicolumn{1}{|c|}{ Kierunek handlu } & Lata & $\begin{array}{c}\text { Wewnątrz } \\
\text { ugrupowania }\end{array}$ & Reszta regionu & Reszta świata \\
\hline Udział eksportu & 1983 & 1,6 & 49,1 & 98,4 \\
\hline Udział eksportu & 2012 & 0,8 & 80,1 & 99,2 \\
\hline Dynamika & - & 50 & 163 & 101 \\
\hline Udział importu & 1983 & 1,7 & 75,8 & 98,3 \\
\hline Udział importu & 2012 & 2,0 & 86,9 & 98,0 \\
\hline Dynamika & - & 118 & 115 & 100 \\
\hline
\end{tabular}

Źródło: jak w tabeli 1.

Wspólnota Gospodarcza Państw Zachodnioafrykańskich (ECOWAS) powstała w 1975 r. Należą do niej: Benin, Burkina Faso, Cape Verde, Cote d'Ivoire, Gambia, Ghana, Gwinea, Gwinea-Bissau, Liberia, Mali, Niger, Nigeria, Senegal, Sierra Leone i Togo.

W przypadku ECOWAS (tabele 9 i 10) dynamika rozwoju eksportu oraz zmiany udziału eksportu w całkowitym eksporcie były najwyższe w handlu z resztą regionu (odpowiednio 9747\% i 240\%), natomiast dynamika rozwoju importu i zmiany udziału importu w całkowitym imporcie były wyższe w handlu wewnątrz ugrupowania (odpowiednio 2843\% i 274\%).

Powstała w 1980 r. Południowoafrykańska Wspólnota Rozwoju (SADC) zrzesza następujące kraje: Angolę, Botswanę, DRK, Lesoto, Madagaskar, Malawi, Mauritius, Mozambik, Namibię, RPA, Swaziland, Tanzanię, Zambię oraz Zimbabwe.

Tabela 9. Dynamika rozwoju eksportu i importu ECOWAS

\begin{tabular}{|l|c|c|c|c|}
\hline \multicolumn{1}{|c|}{ Kierunek handlu } & Lata & $\begin{array}{c}\text { Wewnątrz } \\
\text { ugrupowania }\end{array}$ & Reszta regionu & Reszta świata \\
\hline Eksport (mln USD) & 1975 & 447,3 & 99,5 & 10913,7 \\
\hline Eksport (mln USD) & 2012 & 12529,9 & 9698,6 & 153992,1 \\
\hline Dynamika (\%) & - & 2801 & 9747 & 1411 \\
\hline Import (mln USD) & 1975 & 383,2 & 165,4 & 9636,5 \\
\hline Import (mln USD) & 2012 & 10895,2 & 3919,0 & 93467,5 \\
\hline Dynamika (\%) & - & 2843 & 2369 & 970 \\
\hline
\end{tabular}

Źródło: jak w tabeli 1. 
Tabela 10. Zmiany udziału eksportu i importu ECOWAS w całkowitym eksporcie i imporcie (w \%)

\begin{tabular}{|l|c|c|c|c|}
\hline Kierunek handlu & Lata & $\begin{array}{c}\text { Wewnątrz } \\
\text { ugrupowania }\end{array}$ & Reszta regionu & Reszta świata \\
\hline Udział eksportu & 1975 & 3,9 & 18,2 & 96,1 \\
\hline Udział eksportu & 2012 & 7,5 & 43,6 & 92,5 \\
\hline Dynamika & - & 192 & 240 & 96 \\
\hline Udział importu & 1975 & 3,8 & 30,2 & 96,2 \\
\hline Udział importu & 2012 & 10,4 & 26,5 & 89,6 \\
\hline Dynamika & - & 274 & 88 & 93 \\
\hline
\end{tabular}

Źródło: jak w tabeli 1.

Tabela 11. Dynamika rozwoju eksportu i importu SADC

\begin{tabular}{|l|c|c|c|c|}
\hline \multicolumn{1}{|c|}{ Kierunek handlu } & Lata & $\begin{array}{c}\text { Wewnątrz } \\
\text { ugrupowania }\end{array}$ & Reszta regionu & Reszta świata \\
\hline Eksport (mln USD) & 1980 & 106,3 & 102,5 & 30033,1 \\
\hline Eksport (mln USD) & 2012 & 24336,6 & 4995,9 & 183665,9 \\
\hline Dynamika (\%) & - & 22894 & 4874 & 612 \\
\hline Import (mln USD) & 1980 & 536,6 & 54,7 & 24442,5 \\
\hline Import (mln USD) & 2012 & 32042,0 & 6420,3 & 184129,3 \\
\hline Dynamika (\%) & - & 5971 & 11737 & 753 \\
\hline
\end{tabular}

Źródło: jak w tabeli 1.

Tabela 12. Zmiany udziału eksportu i importu SADC w całkowitym eksporcie i imporcie (w \%)

\begin{tabular}{|l|c|c|c|c|}
\hline \multicolumn{1}{|c|}{ Kierunek handlu } & Lata & $\begin{array}{c}\text { Wewnątrz } \\
\text { ugrupowania }\end{array}$ & Reszta regionu & Reszta świata \\
\hline Udział eksportu & 1980 & 0,4 & 49,1 & 99,6 \\
\hline Udział eksportu & 2012 & 11,7 & 17,0 & 88,3 \\
\hline Dynamika & - & 2925 & 35 & 89 \\
\hline Udział importu & 1980 & 2,1 & 9,3 & 97,9 \\
\hline Udział importu & 2012 & 14,8 & 16,7 & 85,2 \\
\hline Dynamika & - & 705 & 180 & 87 \\
\hline
\end{tabular}

Źródło: jak w tabeli 1.

Można zauważyć (tabele 11 i 12), że dynamika rozwoju eksportu oraz zmiany udziału eksportu i importu w całkowitym eksporcie i imporcie były najwyższe w handlu wewnątrz SADC (odpowiednio 22 894\%, 2925\% i 705\%), a tylko dynamika rozwoju importu była najwyższa w wymianie z resztą regionu (11 737\%). 
Środkowoamerykański Wspólny Rynek (CACM) jest najstarszym badanym ugrupowaniem - powstał w 1960 r. Zrzesza 5 krajów: Gwatemalę, Honduras, Kostarykę, Nikaraguę i Salwador.

$\mathrm{Z}$ danych zamieszczonych w tabelach 13 i 14 wynika, że dynamika rozwoju eksportu i dynamika rozwoju importu były najwyższe wewnątrz CAMC (odpowiednio $20259 \%$ i $24779 \%$ ), podobnie jak zmiany udziału eksportu i importu w całkowitym eksporcie i imporcie (odpowiednio 240\% i 206\%).

Karaibska Wspólnota i Wspólny Rynek (CARICOM) powstała w 1973 r. Do CARICOM należą: Barbados, Gujana, Jamajka, Surinam, Trynidad i Tobago, Belize, Antigua i Barbuda, Dominika, Grenada, Montserrat, St. Kitts/Nevis, St. Lucia i St. Vincent.

W przypadku CARICOM (tabele 15 i 16) dynamika rozwoju eksportu i dynamika rozwoju importu były najwyższe wewnątrz ugrupowania (odpowiednio $2189 \%$ i 2391\%). Także zmiany udziału eksportu i importu w całkowitym eksporcie i imporcie były największe wewnątrz CARICOM (odpowiednio 210\% i 222\%).

Tabela 13. Dynamika rozwoju eksportu i importu CACM

\begin{tabular}{|l|c|c|c|c|}
\hline \multicolumn{1}{|c|}{ Kierunek handlu } & Lata & $\begin{array}{c}\text { Wewnątrz } \\
\text { ugrupowania }\end{array}$ & Reszta regionu & Reszta świata \\
\hline Eksport (mln USD) & 1960 & 30,9 & 235,4 & 412,0 \\
\hline Eksport (mln USD) & 2012 & 6260,0 & 21535,3 & 31072,6 \\
\hline Dynamika (\%) & - & 20259 & 9148 & 7542 \\
\hline Import (mln USD) & 1960 & 33,0 & 302,2 & 480,6 \\
\hline Import (mln USD) & 2012 & 8177,2 & 38739,3 & 53744,9 \\
\hline Dynamika (\%) & - & 24779 & 12819 & 11183 \\
\hline
\end{tabular}

Źródło: jak w tabeli 1.

Tabela 14. Zmiany udziału eksportu i importu CACM w całkowitym eksporcie i imporcie (w \%)

\begin{tabular}{|l|c|c|c|c|}
\hline \multicolumn{1}{|c|}{ Kierunek handlu } & Lata & $\begin{array}{c}\text { Wewnątrz } \\
\text { ugrupowania }\end{array}$ & Reszta regionu & Reszta świata \\
\hline Udział eksportu & 1960 & 7,0 & 88,4 & 93,0 \\
\hline Udział eksportu & 2012 & 16,8 & 77,5 & 83,2 \\
\hline Dynamika & - & 240 & 88 & 89 \\
\hline Udział importu & 1960 & 6,4 & 90,2 & 93,6 \\
\hline Udział importu & 2012 & 13,2 & 82,6 & 86,8 \\
\hline Dynamika & - & 206 & 92 & 93 \\
\hline
\end{tabular}

Źródło: jak w tabeli 1. 
Tabela 15. Dynamika rozwoju eksportu i importu CARICOM

\begin{tabular}{|l|c|c|c|c|}
\hline \multicolumn{1}{|c|}{ Kierunek handlu } & Lata & $\begin{array}{c}\text { Wewnątrz } \\
\text { ugrupowania }\end{array}$ & Reszta regionu & Reszta świata \\
\hline Eksport (mln USD) & 1973 & 143,7 & 1305,5 & 1923,8 \\
\hline Eksport (mln USD) & 2012 & 3146,2 & 12670,6 & 18563,0 \\
\hline Dynamika (\%) & - & 2189 & 971 & 965 \\
\hline Import (mln USD) & 1973 & 146,0 & 1134,6 & 2716,9 \\
\hline Import (mln USD) & 2012 & 3490,5 & 17374,0 & 27416,8 \\
\hline Dynamika (\%) & - & 2391 & 1531 & 1009 \\
\hline
\end{tabular}

Źródło: jak w tabeli 1.

Tabela 16. Zmiany udziału eksportu i importu CARICOM w całkowitym eksporcie i imporcie (w \%)

\begin{tabular}{|l|c|c|c|c|}
\hline \multicolumn{1}{|c|}{ Kierunek handlu } & Lata & $\begin{array}{c}\text { Wewnątrz } \\
\text { ugrupowania }\end{array}$ & Reszta regionu & Reszta świata \\
\hline Udział eksportu & 1973 & 6,9 & 90,1 & 93,1 \\
\hline Udział eksportu & 2012 & 14,5 & 80,1 & 85,5 \\
\hline Dynamika & - & 210 & 89 & 92 \\
\hline Udział importu & 1973 & 5,1 & 88,6 & 94,9 \\
\hline Udział importu & 2012 & 11,3 & 83,3 & 88,7 \\
\hline Dynamika & - & 222 & 94 & 93 \\
\hline
\end{tabular}

Źródło: jak w tabeli 1.

Stowarzyszenie Integracji Ameryki Łacińskiej (LAIA) powstało w 1980 r. Skupia ono Argentynę, Boliwię, Brazylię, Chile, Kolumbię, Kubę, Ekwador, Meksyk, Paragwaj, Peru, Urugwaj i Wenezuelę.

Tabela 17. Dynamika rozwoju eksportu i importu LAIA

\begin{tabular}{|l|c|c|c|c|}
\hline \multicolumn{1}{|c|}{ Kierunek handlu } & Lata & $\begin{array}{c}\text { Wewnątrz } \\
\text { ugrupowania }\end{array}$ & Reszta regionu & Reszta świata \\
\hline Eksport (mln USD) & 1980 & 11191,6 & 32880,1 & 69218,2 \\
\hline Eksport (mln USD) & 2012 & 172531,7 & 453281,8 & 874694,6 \\
\hline Dynamika (\%) & - & 1542 & 1379 & 1264 \\
\hline Import (mln USD) & 1980 & 10682,1 & 34568,6 & 77020,6 \\
\hline Import (mln USD) & 2012 & 173466,0 & 333320,5 & 823073,9 \\
\hline Dynamika (\%) & - & 1624 & 964 & 1069 \\
\hline
\end{tabular}

Źródło: jak w tabeli 1. 
Również w przypadku LAIA (tabele 17 i 18) dynamika rozwoju eksportu i importu były najwyższe wewnątrz ugrupowania (odpowiednio 1542\% i 1624\%), podobnie jak zmiany udziału eksportu i importu w całkowitym eksporcie i imporcie (odpowiednio 119\% i 143\%).

Tabela 18. Zmiany udziału eksportu i importu LAIA w całkowitym eksporcie i imporcie (w \%)

\begin{tabular}{|l|c|c|c|c|}
\hline \multicolumn{1}{|c|}{ Kierunek handlu } & Lata & $\begin{array}{c}\text { Wewnątrz } \\
\text { ugrupowania }\end{array}$ & Reszta regionu & Reszta świata \\
\hline Udział eksportu & 1980 & 13,9 & 74,6 & 86,1 \\
\hline Udział eksportu & 2012 & 16,5 & 72,5 & 83,5 \\
\hline Dynamika & - & 119 & 97 & 97 \\
\hline Udział importu & 1980 & 12,2 & 76,4 & 87,8 \\
\hline Udział importu & 2012 & 17,4 & 65,8 & 82,6 \\
\hline Dynamika & - & 143 & 86 & 94 \\
\hline
\end{tabular}

Źródło: jak w tabeli 1.

Do utworzonego w 1991 r. Wspólnego Rynku Południa (MERCOSUR) należą: Argentyna, Brazylia, Paragwaj, Urugwaj i Wenezuela.

Zgodnie z danymi zawartymi w tabelach 19 i 20 dynamika rozwoju eksportu i dynamika rozwoju importu były najwyższe wewnątrz MERCOSUR (odpowiednio 1305\% i 1204\%), największe były też zmiany udziału eksportu i importu w całkowitym eksporcie i imporcie (odpowiednio 134\% i 115\%).

Stowarzyszenie Państw Azji Południowo-Wschodniej (ASEAN) powstało w 1967 r. i zrzesza następujące kraje: Filipiny, Indonezję, Malezję, Singapur, Tajlandię, Brunei, Wietnam, Laos, Myanmar i Kambodżę.

Tabela 19. Dynamika rozwoju eksportu i importu MERCOSUR

\begin{tabular}{|l|c|c|c|c|}
\hline \multicolumn{1}{|c|}{ Kierunek handlu } & Lata & $\begin{array}{c}\text { Wewnątrz } \\
\text { ugrupowania }\end{array}$ & Reszta regionu & Reszta świata \\
\hline Eksport (mln USD) & 1991 & 5103,4 & 13331,1 & 40871,3 \\
\hline Eksport (mln USD) & 2012 & 66613,8 & 131134,9 & 380496,3 \\
\hline Dynamika (\%) & - & 1305 & 984 & 931 \\
\hline Import (mln USD) & 1991 & 5487,6 & 11639,2 & 31315,8 \\
\hline Import (mln USD) & 2012 & 66097,1 & 102362,0 & 317409,9 \\
\hline Dynamika (\%) & - & 1204 & 879 & 1014 \\
\hline
\end{tabular}

Źródło: jak w tabeli 1. 
Tabela 20. Zmiany udziału eksportu i importu MERCOSUR w całkowitym eksporcie i imporcie (w \%)

\begin{tabular}{|l|c|c|c|c|}
\hline \multicolumn{1}{|c|}{ Kierunek handlu } & Lata & $\begin{array}{c}\text { Wewnątrz } \\
\text { ugrupowania }\end{array}$ & Reszta regionu & Reszta świata \\
\hline Udział eksportu & 1991 & 11,1 & 72,3 & 88,9 \\
\hline Udział eksportu & 2012 & 14,9 & 66,3 & 85,1 \\
\hline Dynamika & - & 134 & 92 & 96 \\
\hline Udział importu & 1991 & 14,9 & 68,0 & 85,1 \\
\hline Udział importu & 2012 & 17,2 & 60,8 & 82,8 \\
\hline Dynamika & - & 115 & 89 & 97 \\
\hline
\end{tabular}

Źródło: jak w tabeli 1.

Na podstawie danych przedstawionych w tabelach 21 i 22 można stwierdzić, że dynamika rozwoju eksportu była najwyższa w przypadku handlu krajów ASEAN z resztą regionu (44 516\%), natomiast dynamika rozwoju importu oraz zmiany udziału eksportu i importu w całkowitym eksporcie i imporcie były najwyższe w handlu wewnątrz ugrupowania (odpowiednio $63706 \%$, 129\% i 226\%).

Do Organizacji Współpracy Gospodarczej (ECO) należą Iran, Pakistan, Turcja, Afganistan, Azerbejdżan, Kazachstan, Kirgistan, Tadżykistan, Turkmenistan i Uzbekistan. Organizacja ta powstała w 1985 r.

Biorąc pod uwagę zaprezentowane dane (tabele 23 i 24), można stwierdzić, że tylko w przypadku zmian udziału eksportu w całkowitym eksporcie analizowany wskaźnik był najwyższy (112\%) w handlu wewnątrz ugrupowania. Dynamika rozwoju eksportu i importu oraz zmiany udziału importu w całkowitym imporcie były najwyższe w handlu krajów ECO z resztą regionu (odpowiednio 2066\%, $1878 \%$ i $106 \%$ ).

Tabela 21. Dynamika rozwoju eksportu i importu ASEAN

\begin{tabular}{|l|c|c|c|c|}
\hline \multicolumn{1}{|c|}{ Kierunek handlu } & Lata & $\begin{array}{c}\text { Wewnątrz } \\
\text { ugrupowania }\end{array}$ & Reszta regionu & Reszta świata \\
\hline Eksport (mln USD) & 1967 & 741 & 1215 & 2929 \\
\hline Eksport (mln USD) & 2012 & 325513,2 & 540864,2 & 928291,6 \\
\hline Dynamika (\%) & - & 43929 & 44516 & 31693 \\
\hline Import (mln USD) & 1967 & 450,3 & 1598,8 & 3865,2 \\
\hline Import (mln USD) & 2012 & 286869,6 & 614875,7 & 933910,0 \\
\hline Dynamika (\%) & - & 63706 & 38459 & 24162 \\
\hline
\end{tabular}

Źródło: jak w tabeli 1. 
Wpływ procesów integracyjnych na handel międzynarodowy...

Tabela 22. Zmiany udziału eksportu i importu ASEAN w całkowitym eksporcie i imporcie (w \%)

\begin{tabular}{|l|c|c|c|c|}
\hline \multicolumn{1}{|c|}{ Kierunek handlu } & Lata & $\begin{array}{c}\text { Wewnątrz } \\
\text { ugrupowania }\end{array}$ & Reszta regionu & Reszta świata \\
\hline Udział eksportu & 1967 & 20,2 & 62,1 & 79,8 \\
\hline Udział eksportu & 2012 & 26,0 & 62,4 & 74,0 \\
\hline Dynamika & - & 129 & 100 & 93 \\
\hline Udział importu & 1967 & 10,4 & 78,0 & 89,6 \\
\hline Udział importu & 2012 & 23,5 & 68,2 & 76,5 \\
\hline Dynamika & - & 226 & 87 & 85 \\
\hline
\end{tabular}

Źródło: jak w tabeli 1.

Tabela 23. Dynamika rozwoju eksportu i importu ECO

\begin{tabular}{|l|c|c|c|c|}
\hline \multicolumn{1}{|c|}{ Kierunek handlu } & Lata & $\begin{array}{c}\text { Wewnątrz } \\
\text { ugrupowania }\end{array}$ & Reszta regionu & Reszta świata \\
\hline Eksport (mln USD) & 1985 & 2446,8 & 8165,8 & 22177,7 \\
\hline Eksport (mln USD) & 2012 & 48429,5 & 168679,0 & 387421,8 \\
\hline Dynamika (\%) & - & 1979 & 2066 & 1747 \\
\hline Import (mln USD) & 1985 & 2407,7 & 8184,7 & 26559,3 \\
\hline Import (mln USD) & 2012 & 33958,3 & 153740,4 & 399582,0 \\
\hline Dynamika (\%) & - & 1410 & 1878 & 1504 \\
\hline
\end{tabular}

Źródło: jak w tabeli 1.

Tabela 24. Zmiany udziału eksportu i importu ECO w całkowitym eksporcie i imporcie (w \%)

\begin{tabular}{|l|c|c|c|c|}
\hline Kierunek handlu & Lata & $\begin{array}{c}\text { Wewnątrz } \\
\text { ugrupowania }\end{array}$ & Reszta regionu & Reszta świata \\
\hline Udział eksportu & 1985 & 9,9 & 76,9 & 90,1 \\
\hline Udział eksportu & 2012 & 11,1 & 77,7 & 88,9 \\
\hline Dynamika & - & 112 & 101 & 99 \\
\hline Udział importu & 1985 & 8,3 & 77,3 & 91,7 \\
\hline Udział importu & 2012 & 7,8 & 81,9 & 92,2 \\
\hline Dynamika & - & 94 & 106 & 101 \\
\hline
\end{tabular}

Źródło: jak w tabeli 1.

Rada Współpracy Państw Zatoki (GCC) powstała w 1981 r. i zrzesza Bahrajn, Kuwejt, Oman, Katar, Arabię Saudyjską oraz Zjednoczone Emiraty Arabskie. 
Tabela 25. Dynamika rozwoju eksportu i importu GCC

\begin{tabular}{|l|c|c|c|c|}
\hline \multicolumn{1}{|c|}{ Kierunek handlu } & Lata & $\begin{array}{c}\text { Wewnątrz } \\
\text { ugrupowania }\end{array}$ & Reszta regionu & Reszta świata \\
\hline Eksport (mln USD) & 1981 & 5603,2 & 65344,1 & 159137,7 \\
\hline Eksport (mln USD) & 2012 & 51190,7 & 780235,9 & 980433,4 \\
\hline Dynamika (\%) & - & 914 & 1194 & 616 \\
\hline Import (mln USD) & 1981 & 4629,9 & 18694,8 & 54940,4 \\
\hline Import (mln USD) & 2012 & 48973,9 & 243884,7 & 460658,2 \\
\hline Dynamika (\%) & - & 1058 & 1305 & 838 \\
\hline
\end{tabular}

Źródło: jak w tabeli 1.

Tabela 26. Zmiany udziału eksportu i importu GCC w całkowitym eksporcie i imporcie (w \%)

\begin{tabular}{|l|c|c|c|c|}
\hline \multicolumn{1}{|c|}{ Kierunek handlu } & Lata & $\begin{array}{c}\text { Wewnątrz } \\
\text { ugrupowania }\end{array}$ & Reszta regionu & Reszta świata \\
\hline Udział eksportu & 1981 & 3,4 & 92,1 & 96,6 \\
\hline Udział eksportu & 2012 & 5,0 & 93,8 & 95,0 \\
\hline Dynamika & - & 147 & 102 & 98 \\
\hline Udział importu & 1981 & 7,8 & 80,2 & 92,2 \\
\hline Udział importu & 2012 & 9,6 & 83,3 & 90,4 \\
\hline Dynamika & - & 123 & 104 & 98 \\
\hline
\end{tabular}

Źródło: jak w tabeli 1.

W przypadku GCC (tabele 25 i 26) dynamika rozwoju eksportu i importu były najwyższe w handlu z resztą regionu (odpowiednio 1194\% i 1305\%), natomiast zmiany udziału eksportu i importu w całkowitym eksporcie i imporcie były najwyższe w handlu wewnątrz ugrupowania (odpowiednio 147\% i 123\%).

W skład Współpracy Gospodarczej Azji i Pacyfiku (APEC) wchodzą: Australia, Brunei, Filipiny, Indonezja, Japonia, Kanada, Korea Południowa, Malezja, Nowa Zelandia, Singapur, Tajlandia, USA, Chiny, Hongkong i Tajwan, Meksyk, Papua Nowa Gwinea, Chile, Peru, Rosja i Wietnam. Organizacja powstała w 1989 r.

W przypadku APEC (tabele 27 i 28) wszystkie 4 badane wskaźniki były najwyższe - ale z niewielką tylko przewagą - w handlu z resztą świata (dane dotyczące wymiany z resztą regionu nie podlegały analizie ze względu na specyfikę krajów członkowskich).

Organizacja Współpracy Gospodarczej Państw Morza Czarnego (BSEC) została założona w 1992 r. i zrzesza Albanię, Armenię, Azerbejdżan, Bułgarię, Grecję, Gruzję, Mołdawię, Rosję, Rumunię, Serbię, Turcję i Ukrainę. 
Wpływ procesów integracyjnych na handel międzynarodowy...

Tabela 27. Dynamika rozwoju eksportu i importu APEC

\begin{tabular}{|l|c|c|c|}
\hline \multicolumn{1}{|c|}{ Kierunek handlu } & Lata & $\begin{array}{c}\text { Wewnątrz } \\
\text { ugrupowania }\end{array}$ & Reszta świata \\
\hline Eksport (mln USD) & 1989 & 839699,3 & 378415,6 \\
\hline Eksport (mln USD) & 2012 & 5955758,4 & 2785274,1 \\
\hline Dynamika (\%) & - & 709 & 736 \\
\hline Import (mln USD) & 1989 & 887310,7 & 408221,9 \\
\hline Import (mln USD) & 2012 & 6086107,7 & 3058037,0 \\
\hline Dynamika (\%) & - & 686 & 749 \\
\hline
\end{tabular}

Źródło: jak w tabeli 1.

Tabela 28. Zmiany udziału eksportu i importu APEC w całkowitym eksporcie i imporcie (w \%)

\begin{tabular}{|l|c|c|c|}
\hline \multicolumn{1}{|c|}{ Kierunek handlu } & Lata & $\begin{array}{c}\text { Wewnątrz } \\
\text { ugrupowania }\end{array}$ & Reszta świata \\
\hline Udział eksportu & 1989 & 68,9 & 31,1 \\
\hline Udział eksportu & 2012 & 68,1 & 31,9 \\
\hline Dynamika & - & 99 & 103 \\
\hline Udział importu & 1989 & 68,5 & 31,5 \\
\hline Udział importu & 2012 & 66,6 & 33,4 \\
\hline Dynamika & - & 97 & 106 \\
\hline
\end{tabular}

Źródło: jak w tabeli 1.

Wszystkie 4 badane wskaźniki były najwyższe w handlu wewnątrz BSEC (tabele 29 i 30) i podobnie jak w przypadku ASEAN ze względu na specyfikę krajów członkowskich dane dotyczące ich wymiany z resztą regionu nie podlegały analizie.

Tabela 29. Dynamika rozwoju eksportu i importu BSEC

\begin{tabular}{|l|c|c|c|}
\hline Kierunek handlu & Lata & $\begin{array}{c}\text { Wewnątrz } \\
\text { ugrupowania }\end{array}$ & Reszta świata \\
\hline Eksport (mln USD) & 1992 & 6812,3 & 67715,8 \\
\hline Eksport (mln USD) & 2012 & 126235,3 & 791266,2 \\
\hline Dynamika & - & 1853 & 1169 \\
\hline Import (mln USD) & 1992 & 7717,9 & 89205,6 \\
\hline Import (mln USD) & 2012 & 156958,1 & 696427,9 \\
\hline Dynamika & - & 2034 & 781 \\
\hline
\end{tabular}

Źródło: jak w tabeli 1. 
Tabela 30. Zmiany udziału eksportu i importu BSEC w całkowitym eksporcie i imporcie (w \%)

\begin{tabular}{|l|c|c|c|}
\hline \multicolumn{1}{|c|}{ Kierunek handlu } & Lata & $\begin{array}{c}\text { Wewnątrz } \\
\text { ugrupowania }\end{array}$ & Reszta świata \\
\hline Udział eksportu & 1992 & 9,1 & 90,9 \\
\hline Udział eksportu & 2012 & 13,8 & 86,2 \\
\hline Dynamika & - & 152 & 95 \\
\hline Udział importu & 1992 & 8,0 & 92,0 \\
\hline Udział importu & 2012 & 18,4 & 81,6 \\
\hline Dynamika & - & 230 & 89 \\
\hline
\end{tabular}

Źródło: jak w tabeli 1.

Tabela 31. Dynamika rozwoju eksportu i importu CIS

\begin{tabular}{|l|c|c|c|}
\hline \multicolumn{1}{|c|}{ Kierunek handlu } & Lata & $\begin{array}{c}\text { Wewnątrz } \\
\text { ugrupowania }\end{array}$ & Reszta świata \\
\hline Eksport (mln USD) & $1992^{\text {a }}$ & 3703,2 & 44124,9 \\
\hline Eksport (mln USD) & 2012 & 127551,7 & 670835,9 \\
\hline Dynamika (\%) & - & 3444 & 1520 \\
\hline Import (mln USD) & $1992^{\text {a }}$ & 4114,3 & 39350,7 \\
\hline Import (mln USD) & 2012 & 145105,4 & 395949,3 \\
\hline Dynamika (\%) & - & 3527 & 1006 \\
\hline
\end{tabular}

a ugrupowanie utworzono w 1991 r., ale dane są dostępne od 1992 r.

Źródło: jak w tabeli 1.

Tabela 32. Zmiany udziału eksportu i importu CIS w całkowitym eksporcie i imporcie (w \%)

\begin{tabular}{|l|c|c|c|}
\hline \multicolumn{1}{|c|}{ Kierunek handlu } & Lata & $\begin{array}{c}\text { Wewnątrz } \\
\text { ugrupowania }\end{array}$ & Reszta świata \\
\hline Udział eksportu & $1992^{\text {a }}$ & 7,7 & 92,3 \\
\hline Udział eksportu & 2012 & 16,0 & 84,0 \\
\hline Dynamika & - & 208 & 91 \\
\hline Udział importu & $1992^{\text {a }}$ & 9,5 & 90,5 \\
\hline Udział importu & 2012 & 26,8 & 73,2 \\
\hline Dynamika & - & 282 & 81 \\
\hline
\end{tabular}

${ }^{a}$ ugrupowanie utworzono w 1991 r., ale dane są dostępne od 1992 r.

Źródło: jak w tabeli 1.

Ostatnim badanym ugrupowaniem była Wspólnota Niepodległych Państw (CIS), która powstała w 1991 r. po upadku ZSRR. Do Wspólnoty należą: Rosja, 
Ukraina, Białoruś, Kazachstan, Kirgistan, Mołdawia, Turkmenistan, Uzbekistan, Tadżykistan, Armenia, Azerbejdżan i Gruzja.

Ponownie wszystkie 4 badane wskaźniki były najwyższe w handlu wewnątrz ugrupowania (tabele 31 i 32). Podobnie też jak w przypadku BSEC oraz ASEAN ze względu na specyfikę krajów członkowskich dane dotyczące wymiany krajów CIS z resztą regionu nie podlegały analizie.

\section{Interpretacja wyników badań}

Dane przedstawione w tabelach 1-32 pozwalają na następującą interpretację przeprowadzonych badań:

1) dynamika rozwoju eksportu: na 16 badanych ugrupowań regionalnych w 10 przypadkach wystąpił największy przyrost eksportu w handlu wewnątrz ugrupowania (w porównaniu z eksportem do krajów regionu i do reszty świata),

2) dynamika rozwoju importu: na 16 badanych ugrupowań regionalnych również w 10 przypadkach wystąpił największy przyrost importu w handlu wewnątrz ugrupowania (w porównaniu z importem z krajów regionu i z reszty świata),

3) zmiany udziału eksportu w całkowitym eksporcie: na 16 badanych ugrupowań regionalnych w 13 przypadkach wystąpił największy przyrost udziału eksportu w całkowitym eksporcie wewnątrz ugrupowania (w porównaniu z udziałem w całkowitym eksporcie eksportu do krajów regionu i do reszty świata),

4) zmiany udziału importu w całkowitym imporcie: na 16 badanych ugrupowań regionalnych w 15 przypadkach wystąpił największy przyrost udziału importu w całkowitym imporcie wewnątrz ugrupowania (w porównaniu z udziałem w całkowitym imporcie importu z krajów regionu i z reszty świata).

W większości badanych układów i porozumień regionalnych (10 na 16 ugrupowań) zaobserwowano, że stopa wzrostu eksportu i importu wewnętrznego jest wyższa niż stopa wzrostu handlu w ramach reszty regionu i reszty świata, można zatem zaryzykować stwierdzenie, że przyczyną takiego stanu rzeczy są pozytywne efekty procesu międzynarodowej integracji gospodarczej w analizowanych ugrupowaniach.

W większości badanych układów i porozumień regionalnych (13 w przypadku eksportu i 15 w przypadku importu na 16 ugrupowań) zaobserwowano, że udział eksportu i importu wewnętrznego w całkowitym eksporcie i imporcie jest wyższy niż udział eksportu i importu z resztą świata w całkowitym eksporcie i imporcie, zatem ponownie można zaryzykować stwierdzenie, że przyczyną takiego stanu rzeczy są pozytywne efekty procesu międzynarodowej integracji gospodarczej w analizowanych ugrupowaniach. 


\section{Zakończenie}

W ramach niniejszego opracowania podjęto próbę zweryfikowania tezy, że pozytywne efekty procesów międzynarodowej regionalnej integracji gospodarczej krajów rozwijających się prowadzą do wzrostu wartości wymiany handlowej zarówno w zakresie stopy wzrostu eksportu i importu, jak i wzrostu udziału eksportu i importu w całości wymiany handlowej wewnątrz tworzonych ugrupowań (licząc od daty powstania ugrupowania do 2012 r.). Zdaniem autora przeprowadzonych badań taka próba powiodła się.

Wydaje się zasadne przeprowadzenie kolejnych badań i analiz polegających na porównaniu efektów integracji w kolejnych jej stadiach: od dat utworzenia ugrupowania, przez stadium strefy wolnego handlu, aż do unii celnej. W ten sposób można będzie zaobserwować, jak w miarę redukowania kolejnych barier we wzajemnym handlu rozwijała się wymiana handlowa (wewnątrz ugrupowania, z krajami danego regionu i z resztą świata).

\section{Literatura}

Anderson J.E., Yotov Y. [2011], Terms of Trade and Global Efficiency Effects of Free Trade Agreements, 1990-2002, NBER Research Working Paper No. 17003, http:// www.nber.org/papers/w17003.pdf (dostęp: 3.06.2015).

Bagiński P., Czaplicka K., Szczyciński J. [2009], Międzynarodowa współpraca na rzecz. rozwoju, Polskie Wydawnictwo Ekonomiczne, Warszawa.

Baier S.L., Bergstrand J.H. [2007], Do Free Trade Agreements Actually Increase Members' International Trade?, ,Journal of International Economics”, vol. 71, nr 1, http:// dx.doi.org/10.1016/j.jinteco.2006.02.005.

Baier S.L., Bergstrand J.H., Feng M. [2014], Economic Integration Agreements and the Margins Of International Trade, ,Journal of International Economics”, vol. 93, nr 2, http://dx.doi.org/10.1016/j.jinteco.2014.03.005.

Balassa B. [1962], The Theory of Economic Integration, George Allen \& Unwin Ltd, London.

Bożyk P., Misala J., Puławski M. [1999], Międzynarodowe stosunki ekonomiczne, Polskie Wydawnictwo Ekonomiczne, Warszawa.

Chen M.X., Mattoo A. [2011], Regionalism in Standards: Good or Bad for Trade?, „Canadian Journal of Economics”, vol. 41, nr 3, http://dx.doi.org/10.1111/j.15405982.2008.00488.x.

Chen N., Novy D. [2011], Gravity, Trade Integration, and Heterogeneity across Industries, ,Journal of International Economics”, vol. 85, nr 2, http://dx.doi.org/10.1016/ j.jinteco.2011.07.005.

Czarny E., Folfas P., Śledziewska K., Witkowski B. [2013], Wpływ integracji monetarnej na wymiane towarowa w warunkach kryzysu gospodarczego, Materiały i Studia, nr 300, Narodowy Bank Polski, Instytut Ekonomiczny, Warszawa. 
Czarny E., Menkes J., Śledziewska K. [2009], Regionalizacja a liberalizacja handlu międzynarodowego - analiza empiryczna [w:] Determinanty $i$ wyzwania gospodarki światowej, red. E. Najlepszy, M. Bartosik-Purgat, Uniwersytet Ekonomiczny w Poznaniu, Poznań.

Eicher T.S., Henn Ch., Papageorgiou Ch. [2012], Trade Creation and Diversion Revisited: Accounting for Model Uncertainty and Natural Trading Partner Effects, ,Journal of Applied Econometrics", vol. 27, nr 2, http://dx.doi.org/10.1002/jae.1198.

Freund C., Ornelas E. [2010], Regional Trade Agreements, „Annual Review of Economics”, vol. 2, nr 1, http://dx.doi.org/10.1146/annurev.economics.102308.124455.

Ghosh S., Yamarik S. [2004], Does Trade Creation Measure up? A Reexamination of the Effects of Regional Trading Arrangements, ,Economics Letters”, vol. 82, nr 2, http:// dx.doi.org/10.1016/j.econlet.2003.06.001.

Hansen J.D. [2003], Ekonomiczne aspekty integracji europejskiej, Oficyna Ekonomiczna, Kraków.

Helpman E., Melitz M., Rubinstein Y. [2008], Estimating Trade Flows: Trading Partners and Trading Volumes, ,The Quarterly Journal of Economics”, vol. 123, nr 2, http:// dx.doi.org/10.1162/qjec.2008.123.2.441.

Hoekman B., Ng F., Olarreaga M. [2002], Eliminating Excessive Tariffs on Exports of Least Developed Countries, ,The World Bank Economic Review”, vol. 16(1), http:// dx.doi.org/10.1093/wber/16.1.1.

Kindleberger C.P. [1966], European Integration and the International Corporation, „Columbia Journal of World Business”, nr 1.

Kovak B.K. [2013], Regional Effects of Trade Reform: What is the Correct Measure of Liberalization?, „American Economic Review”, vol. 103, nr 5, http://dx.doi. org/10.1257/aer.103.5.1960.

Kraje rozwijajace się w światowym systemie gospodarczym [2007], red. S. Miklaszewski, Difin, Warszawa.

Lee H., Kim C. [2012], The Impact of Trade Facilitation on the Extensive and Intensive Margins of Trade: An Application for Developing Countries, ,Journal of East Asian Economic Integration", vol. 16, nr 1, http://dx.doi.org/10.11644/kiep.jeai.2012.16.1.243.

Magee C.S.P. [2008], New Measures of Trade Creation and Trade Diversion, ,Journal of International Economics", vol. 75, nr 2, http://dx.doi.org/10.1016/j.jinteco.2008.03.006.

Melo J. de, Tsikata Y. [2014], Regional Integration in Africa: Challenges and Prospects, http://www.imvf.org/ficheiros/file/wp2014-037_1.pdf (dostęp: 3.06.2015).

Międzynarodowe stosunki gospodarcze [2006], red. J. Rymarczyk, Polskie Wydawnictwo Ekonomiczne, Warszawa.

Nowak-Lehmann F., Herzer D., Martinez-Zarzoso I., Vollmer S. [2007], The Impact of a Customs Union between Turkey and the EU on Turkey's Exports to the EU, „Journal of Common Market Studies”, vol. 45, nr 3, http://dx.doi.org/10.1111/ j.1468-5965.2007.00728.x.

Piekutowska A. [2014], Efekty integracji regionalnej w krajach rozwijajacych sie, ,Studia Ekonomiczne. Zeszyty Naukowe Uniwersytetu Ekonomicznego w Katowicach”, nr 166.

Portugal-Perez A., Wilson J.S. [2012], Export Performance and Trade Facilitation Reform: Hard and Soft Infrastructure, ,World Development”, vol. 40, nr 7, http:// dx.doi.org/10.1016/j.worlddev.2011.12.002. 
Pozaeuropejskie ugrupowania integracyjne [2006], red. J. Rymarczyk, M. Wróblewski, Oficyna Wydawnicza Arboretum, Wrocław.

Rynarzewski T. [2013], Refleksje o dylematach wpływu handlu zagranicznego na rozwój gospodarczy krajów słabo zaawansowanych ekonomicznie, ,Studia Oeconomica Posnaniensia", vol. 1, nr 1(250).

Soete S., Hove J.V. [2013], Dissecting the Trade Effects of Europe's Economic Integration Agreements, University of Leuven, https:/ghum.kuleuven.be/ggs/documents/ggs-paperjan-en-sophie.pdf (dostęp: 3.06.2015).

Świerkocki J. [2004], Zarys międzynarodowych stosunków gospodarczych, Polskie Wydawnictwo Ekonomiczne, Warszawa.

The Least Developed Countries Report 2012 [2012], UNCTAD, New York-Geneva, http://unctad.org/en/PublicationsLibrary/ldc2012_en.pdf (dostęp: 3.06.2015).

Witkowska Z., Wysokińska J. [1999], Integracja europejska. Rozwój rynków, Wydawnictwo Naukowe PWN, Warszawa-Łódź.

Wybrane problemy procesów integracyjnych we współczesnej gospodarce światowej [1995], red. E. Oziewicz, Wydawnictwo Uniwersytetu Gdańskiego, Gdańsk.

Venables A.J. [2003], Winners and Losers from Regional Trade Agreements, „Economic Journal", vol. 113(490), http://dx.doi.org/10.1111/1468-0297.t01-1-00155/.

Yannopoulos G.N. [1990], Foreign Direct Investment and European Integration. The Evidence from the Formative Years of the European Community, ,Journal of The Common Market Studies", vol. 28, nr 3, http://dx.doi.org/10.1111/j.1468-5965.1990. tb00366.x.

Zielińska-Głębocka A. [1997], Wprowadzenie do ekonomii międzynarodowej. Teoria handlu i polityki handlowej, Wydawnictwo Uniwersytetu Gdańskiego, Gdańsk.

\section{The Impact of Integration Processes on International Trade - the Case of Developing Countries}

(Abstract)

The study attempts to verify the hypothesis that the positive effects of regional integration processes of international business in developing countries lead to an increase in the value of trade, both in terms of growth rates of exports and imports, as well as an increase in the share of exports and imports in the total exchange inside the created groups. The international integration of developing countries brings them benefits as a result of customs duties and other barriers between themselves being reduced. The growth rate of exports and imports within the group is higher than the rate of growth of trade in the rest of the region and the rest of the world, and the share of exports and imports throughout the internal exports and imports is higher than the share of exports and imports with the rest of the world in total exports and imports.

Keywords: developing countries, the effects of regional integration, international trade, regional groupings. 